\title{
Inhibition of JNK Phosphorylation by Curcumin Analog C66 Protects LPS-Induced Acute Lung Injury [Corrigendum]
}

Xiao Z, Xu F, Zhu X, et al. Drug Des Devel Ther. 2019;1:4161-4171.

The authors have advised Funding section on page 4170 should be:

\section{Funding}

This study was supported by the Natural Science Funding of China (21572166 to Y.Z., and 81770850 to X.S.),
Zhejiang Provincial Natural Science Funding (LY19H 310001 to B.Z., and LY17H050007 to X.S.), and Project for Science and Technology of Huzhou (2015GY08 to L.G.).

\section{Publish your work in this journal}

Drug Design, Development and Therapy is an international, peerreviewed open-access journal that spans the spectrum of drug design and development through to clinical applications. Clinical outcomes, patient safety, and programs for the development and effective, safe, and sustained use of medicines are a feature of the journal, which has also been accepted for indexing on PubMed Central. The manuscript management system is completely online and includes a very quick and fair peer-review system, which is all easy to use. Visit http://www. dovepress.com/testimonials.php to read real quotes from published authors. 